\title{
Superoxide, hydrogen peroxide and singlet oxygen in hematoporphyrin derivative-cysteine, -NADH and -light systems
}

\author{
Garry R. Buettner and Robert D. Hall \\ Laboratory of Molecular Biophysics, National Institute of Environmental Health Sciences, \\ Research Triangle Park, NC (U.S.A.)
}

(Received 15 September 1986)

Key words: Singlet oxygen; Superoxide; Hematoporphyrin derivative; Cysteine; Glutathione; NADH; (Spin trapping)

Hematoporphyrin derivative and light in the presence of cysteine or glutathione were found to convert oxygen to superoxide and hydrogen peroxide at $\mathrm{pH}<$ approx. 6.5, while at $\mathrm{pH}>6.5$ no superoxide or hydrogen peroxide production was observed. However, at $\mathrm{pH}$ values greater than 6.5 the rate of oxygen consumption increased. This rate paralleled the acid dissociation curve of the cysteine thiol group and is consistent with the chemical quenching of ${ }^{1} \mathrm{O}_{2}$ by cysteine. The superoxide and hydrogen peroxide formation observed below pH 6.5 appeared not to be related to the singlet oxygen production of hematoporphyrin derivative. In addition, superoxide and hydrogen peroxide production was observed with hematoporphyrin derivative and light in the presence of NADH, both above and below pH 6.5. Direct detection of singlet oxygen luminescence at $1268 \mathrm{~nm}$ in the hematoporphyrin derivative-light system $\left({ }^{2} \mathrm{H}_{2} \mathrm{O}\right.$ as solvent) revealed an apparent linear increase in the singlet oxygen emission intensity as the $\mathrm{p}^{2} \mathrm{H}$ was raised from 7.0 to 10.0 . Azide efficiently quenched this observed emission. In addition, at $\mathrm{p}^{2} \mathrm{H} 7.4,1 \mathrm{mM}$ cysteine resulted in a $40 \%$ reduction of the singlet oxygen luminescence, while at $\mathrm{p}^{2} \mathrm{H} 9.4$ the signal was quenched by over $95 \%$ (under the experimental conditions employed). In total, we interpret these results as consistent with the chemical quenching of ${ }^{1} \mathrm{O}_{2}$ by the ionized thiol group of cysteine.

\section{Introduction}

Hematoporphyrin derivative (HPD or Photofrin II) is used as an investigational drug in the treatment of malignant disease by photodynamic therapy. The most active component of hematoporphyrin derivative is thought to be the dihematoporphyrin ether [1,2] or ester [3] or even a triether/ester [4]. Hematoporphyrin derivative is selectively retained by malignant tumors [5-7], and excitation with red light $(630 \mathrm{~nm})$ results in the photodynamic destruction of the tumor tissue. The cytotoxic agent of hematoporphyrin derivative photosensitization has been shown to arise

Correspondence: G.R. Buettner, GSF, Institut für Strahlenbiologie, D-8042 Neuherberg, F.R.G. from oxygen [8-10]. Cytotoxicity has been attributed to singlet oxygen [11-13], an excited state of molecular oxygen, and to the hydroxyl radical $[13,14]$. In vitro studies have demonstrated that hematoporphyrin produces both free radicals [15-19] and singlet oxygen [12,17].

In one spin trapping study, observations were made which were consistent with the formation of hydroxyl radical by hematoporphyrin and light [16]. In a different study using elements of the superoxide dismutase assay, no significant superoxide production was observed with low-intensity steady-state irradiation of hematoporphyrin derivative [20]. However, Reddi et al. [21] have reported the photoionization of hematoporphyrin and the concomitant formation of superoxide in low quantum yield, less than $5 \%$, during laser flash photolysis. In the absence of reducing agents, the 
most likely reactions leading to the formation of the superoxide radical are

$$
\begin{aligned}
& \mathrm{HPD}+h \nu \rightarrow \mathrm{HPD}^{+}+\mathrm{e}^{-} \\
& \mathrm{e}^{-}+\mathrm{O}_{2} \rightarrow \mathrm{O}_{2}^{-}
\end{aligned}
$$

Studies utilizing reducing agents have shown that $\mathrm{O}_{2}^{\overline{-}}, \mathrm{H}_{2} \mathrm{O}_{2}$, and $\mathrm{OH}$ can be produced [22-24].

The photoreduction of hematoporphyrin has been observed with electron spin resonance [18]. We report here the hematoporphyrin derivativemediated photoproduction of $\mathrm{O}_{2}^{-}$in the presence of NADH and at $\mathrm{pH}<6.5$ with cysteine. We also report that singlet oxygen appears to react with the ionized thiol group of cysteine.

\section{Materials and Methods}

Photofrin II, i.e., a purified preparation of hematoporphyrin derivative, was purchased from Oncology Research and Development, Inc., Cheektowaga, NY, U.S.A., and was used as received. Bovine serum albumin, catalase and superoxide dismutase were from Sigma Chemical Co., St. Louis, MO. Deuterium oxide (99.8 atom\%), deuterated phosphoric acid, deuterium chloride, sodium deuteroxide, and the spin trapping agent, DMPO (5,5-dimethylpyrroline $N$-oxide), were from Aldrich Chemical Co., Milwaukee, WI. The DMPO was purified as in Ref. 25 and stored at $4^{\circ} \mathrm{C}$ as an aqueous solution. The concentration of the stock solution was determined using $\varepsilon_{232}=$ $7700 \mathrm{M}^{-1} \cdot \mathrm{cm}^{-1}$ in ethanol [26]. The borax was from Baker. In the oxygen uptake and spin trapping experiments, solutions were prepared in 50 $\mathrm{mM}$ phosphate buffer, with Photofrin II at a final concentration that produced an absorbance of 2.0 at $365 \mathrm{~nm}(1 \mathrm{~cm}$ light path), unless noted otherwise. For the study of the ${ }^{1} \mathrm{O}_{2}$ emission vs. $\mathrm{p}^{2} \mathrm{H}$, the initial absorbance of the hematoporphyrin derivative Soret band was $0.48 \pm 0.02(1 \mathrm{~cm}$ light path). The study of the quenching of the ${ }^{1} \mathrm{O}_{2}$ emission by cysteine was carried out with solutions of hematoporphyrin derivative at initial Soret absorbances of both 0.48 and 2.0. Ten millimolar buffer salts were used in both emission studies. The absorbance at $365 \mathrm{~nm}(1 \mathrm{~cm}$ path) of Photofrin II has been reported to be 102 for a solution containing $1 \mathrm{mg} / \mathrm{ml}$ [27].
Electron spin resonance (ESR) spectra were obtained with a Varian E-109B ESR spectrometer using a $\mathrm{TM}_{110}$ cavity and aqueous sample cell. Oxygen uptake was monitored with a Yellow Springs Instrument Co., Inc., Model 53 Biological Oxygen Monitor. A $100 \mathrm{~W}$ quartz tungsten-halogen lamp (Oriel) operating at $3200 \mathrm{~K}$ was used as a white light soruce. The light incident on the sample was filtered through an Oriel IR blocking filter (No. 5205) and an Oriel long pass filter (No. $5130,50 \%$ transmission cut at $530 \mathrm{~nm}$ ). Using a Yellow Springs Instrument Model 65A radiometer and a Model 6551 probe, the filtered light intensity incident on the sample was determined to be $480 \mathrm{~J} \cdot \mathrm{m}^{-2} \cdot \mathrm{s}^{-1}$ for the oxygen uptake exeriments and $420 \mathrm{~J} \cdot \mathrm{m}^{-2} \cdot \mathrm{s}^{-1}$ for the electron spin resonance experiments, assuming that the $\mathrm{TM}_{110}$ cavity grid transmits $75 \%$ of the incident light. In the ${ }^{2} \mathrm{H}_{2} \mathrm{O}$ experiments the $\mathrm{p}^{2} \mathrm{H}$ was determined using a standard $\mathrm{pH}$ meter and probe and the relationship, $\mathrm{p}^{2} \mathrm{H}=$ (meter reading calibrated for $\left.\mathrm{pH}\right)+$ 0.4 [28].

Singlet oxygen luminescence at $1268 \mathrm{~nm}$ was monitored as described by Hall and Chignell [29]. All luminescence experiments were done in ${ }^{2} \mathrm{H}_{2} \mathrm{O}$ using sodium phosphate to buffer solutions with $\mathrm{p}^{2} \mathrm{H} \leq 8.4$ and borax to buffer solutions with $\mathrm{p}^{2} \mathrm{H}$ $\leq 8.4$. The borax (listed by the manufacturer as a decahydrate) contributed no more than $0.25 \mathrm{~mol} \%$ water to the buffers made with it. No significant changes in $\mathrm{p}^{2} \mathrm{H}$ were noted following irradiation of samples. Excitation of the samples was carried out using a $200 \mathrm{~W}$ mercury arc lamp and a combination of $10 \mathrm{~cm}$ water and Schott KV470 and KG3 filters to excite the hematoporphyrin above the Soret band. Acquisition of the singlet oxygen emission spectra took about $10 \mathrm{~min}$, so a flow cell was used to minimize photodegradation of the Photofrin II [29]. Flow rates were high enough in the experiments to maintain the loss of Photofrin II, as detected by changes in the Soret absorbance, below $10 \%$.

\section{Results}

\section{Superoxide production}

Using the ESR spin trapping technique $[30,31]$ the hematoporphyrin derivative-photosensitized formation of the superoxide spin adduct of DMPO 
was observed in the presence of cysteine at $\mathrm{pH}<$ 6.5 (Fig. 1). Inclusion of superoxide dismutase at 100 units $/ \mathrm{ml}$ suppressed the formation of this spin adduct. If the $\mathrm{pH}$ was increased to greater than 6.5 , the spectrum of the superoxide spin adduct of DMPO was no longer observed, but was replaced by spectra consistent with the DMPO hydroxyl and cysteinyl free radical adducts as
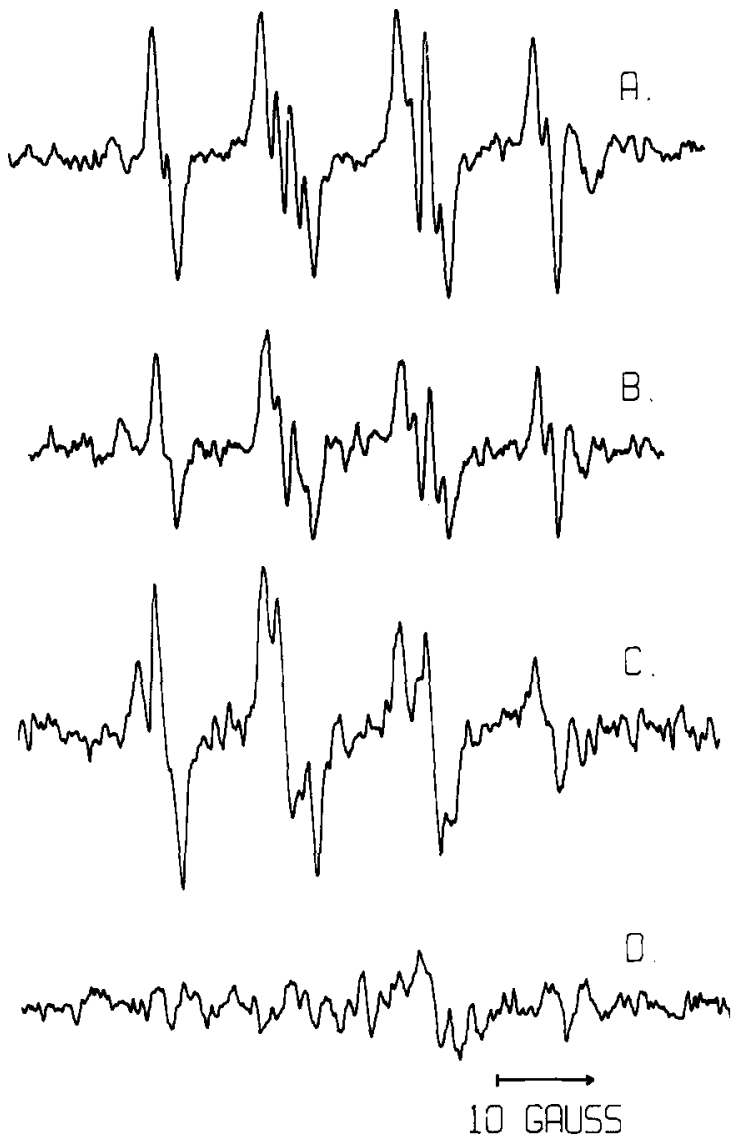

Fig. 1. $\mathrm{O}_{2}^{\top}$ spin trapping solutions contained $50 \mathrm{mM}$ DMPO and Photofrin II, $A_{365}(1 \mathrm{~cm})=2$ in $\mathrm{pH} 7.0$ phosphate or $\mathrm{pH}$ 5.0 citrate buffer. Irradiation of the sample began at the same time as the scan. (A) The superoxide spin adduct of DMPO $\left(a^{\mathrm{N}}=14.2 \mathrm{G}, a_{\beta}^{\mathrm{H}}=11.3 \mathrm{G}, a_{a}^{\mathrm{H}}=1.3 \mathrm{G}\right)$, see Ref. 30. The solution contained $4 \mathrm{mM}$ cysteine in $\mathrm{pH} 5.0$ citrate buffer; instrument settings were: gain, $5 \cdot 10^{4}$; modulation amplitude, 0.5 gauss; time constant, $1 \mathrm{~s}$; power, $20 \mathrm{~mW}$; scan 100 gauss $/ 8$ min. (B) same as A, except cysteine was replaced with glutathione, $4 \mathrm{mM}$. (C) $5 \mathrm{mg} \mathrm{NADH} / 3 \mathrm{ml}$ of $\mathrm{pH} 7.0$ phosphate buffer; instrument settings were: gain, $3.2 \cdot 10^{4}$; modulation amplitude, 1 gauss; time constant, $1 \mathrm{~s}$, power, $20 \mathrm{~mW}$; scan, 100 gauss $/ 4 \mathrm{~min}$. (D) no reducing agent present; all conditions are as in $A$ and $B$ above. previously reported [23]; the intensity of these signals was unaffected by the presence of superoxide dismutase. Exactly parallel results were observed when cysteine was replaced with glutathione.

When NADH was present as the reducing agent in the hematoporphyrin derivative spin trapping solution, DMPO-superoxide and -hydroxyl radical adducts were observed over the $\mathrm{pH}$ range 5-8.

\section{Oxygen uptake}

In oxygen uptake experiments, the irradiation of hematoporphyrin derivative in the presence of cysteine resulted in a $\mathrm{pH}$-dependent consumption of oxygen. At $\mathrm{pH}<6.5$ a constant rate of oxygen uptake was observed; however, as the $\mathrm{pH}$ was increased, the rate of oxygen consumption increased (Fig. 2). This rate of increase follows the ionization curve of the cysteine thiol, $\mathrm{p} K_{\mathrm{a}}=8.3$. From this we conclude that the primary reaction is with ionized thiol. When catalase was added to the oxygen uptake solutions after irradiation, there was a return of oxygen only at $\mathrm{pH}<6.5$. This indicates that oxygen was converted to hydrogen peroxide (in amounts detectable using the oxygen monitor) only below pH 6.5.

\section{${ }^{2} \mathrm{H}_{2} \mathrm{O}$ effect}

The lifetime of singlet oxygen is about $4.2 \mu \mathrm{s}$ in $\mathrm{H}_{2} \mathrm{O}$ and $55.0 \mu \mathrm{s}$ in ${ }^{2} \mathrm{H}_{2} \mathrm{O}$ [32]. Its longer lifetime in ${ }^{2} \mathrm{H}_{2} \mathrm{O}$ increases the likelihood that reactions involving singlet oxygen will occur when ${ }^{2} \mathrm{H}_{2} \mathrm{O}$

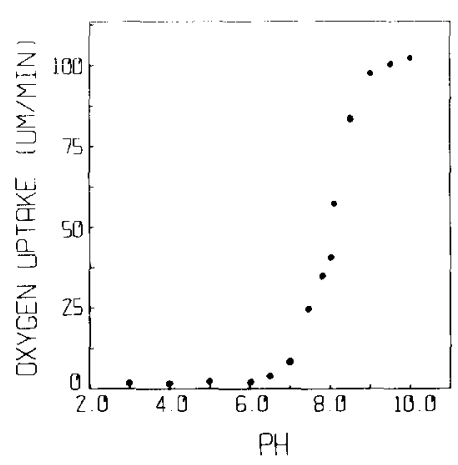

Fig. 2. Oxygen uptake vs. pH. The solutions contained Photofrin II in $50 \mathrm{mM}$ citrate, phosphate, or Tris buffer. No significant oxygen consumption was noted prior to the introduction of cysteine at a final concentration of $1 \mathrm{mM}$ to the illuminated hematoporphyrin derivative solution. 
replaces water as the solvent. When ${ }^{2} \mathrm{H}_{2} \mathrm{O}$ was substituted for $\mathrm{H}_{2} \mathrm{O}$ in the hematoporphyrin derivative-cysteine system, no change in the rate of oxygen uptake occurred at $\mathrm{p}^{2} \mathrm{H}$ 5.0. However, at $\mathrm{p}^{2} \mathrm{H} 7.4$ the rate of oxygen uptake increased by a factor of 1.8 over the rate in $\mathrm{H}_{2} \mathrm{O}$ solution, $\mathrm{pH}$ 7.4. In addition, 2.5 and $10 \mathrm{mM}$ azide inhibited the rate of oxygen uptake at $\mathrm{pH} 7.4$ and $\mathrm{p}^{2} \mathrm{H} 7.4$ in a concentration-dependent manner, but had no detectable effect on the rate of oxygen uptake in the pH 5.0 and $\mathrm{p}^{2} \mathrm{H} 5.0$ solutions. This observation, in conjunction with the spin trapping results above, suggests that the singlet oxygen-cysteine reaction is more important at $\mathrm{pH}>6.5$, while singlet oxygen is not significantly involved in the oxygen uptake below pH 6.5 .

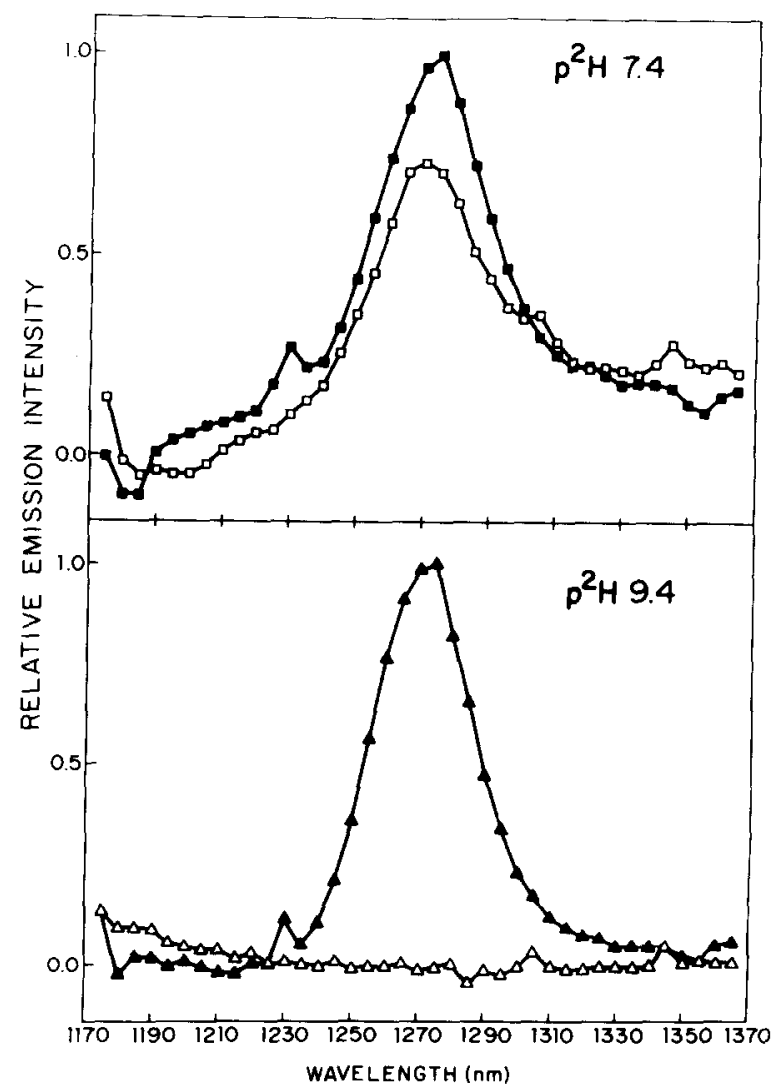

Fig. 3. Singlet oxygen at $1268 \mathrm{~nm}$. Singlet oxygen emission spectrum produced by illumination of Photofrin II in buffered deuterium oxide at $\mathrm{p}^{2} \mathrm{H} 7.4$ (E); $7.4+1 \mathrm{mM}$ cysteine $(\square) ; \mathrm{p}^{2} \mathrm{H}$ $9.4(\Delta) ; \mathrm{p}^{2} \mathrm{H} 9.4+1 \mathrm{mM}$ cysteine $(\Delta)$. The initial Soret absorbance was 2.0 .

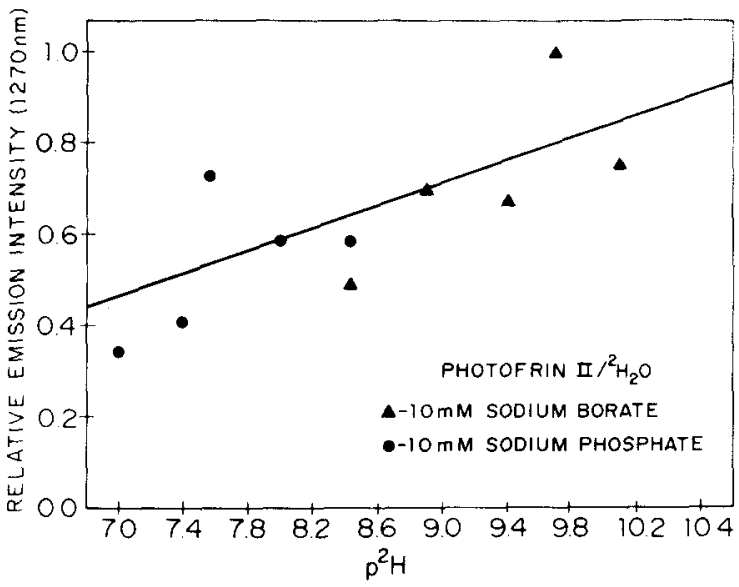

Fig. 4. Singlet oxygen emission intensity. Singlet oxygen emission intensity of Photofrin II in buffered deuterium oxide as a function of $\mathrm{p}^{2} \mathrm{H}$ : (๑) $10 \mathrm{mM}$ phosphate buffer; (A) $10 \mathrm{mM}$ borate buffer.

\section{Singlet oxygen detection at $1268 \mathrm{~nm}$}

As additional evidence that thiols quench singlet oxygen, we looked directly at the singlet oxygen luminescence of hematoporphyrin derivative-light systems in the presence and absence of cysteine. At $p^{2} \mathrm{H} 7.4$ the presence of $1 \mathrm{mM}$ cysteine reduced the singlet oxygen emission intensity by approximately $40 \%$, while at $\mathrm{p}^{2} \mathrm{H} 9.4$ the intensity is reduced by over $95 \%$ (Fig. 3). Background spectr: were obtained using $5 \mathrm{mM}$ sodium azide to sup. press the singlet oxygen emission [29,33]. This concentration was sufficient to completely eliminate the singlet oxygen band at $1268 \mathrm{~nm}$ without significantly affecting long-wavelength luminescence associated with the Photofrin II itself. We also observed an apparent linear increase in the integrated intensity of the $1268 \mathrm{~nm}$ luminescence with an increase in $\mathrm{p}^{2} \mathrm{H}$ (within the limits of the noise). Between $\mathrm{p}^{2} \mathrm{H} 7.0$ and $\mathrm{p}^{2} \mathrm{H} 10.0$ an increase in intensity of approximately 1.75 occurs (Fig. 4).

\section{Conclusions}

The production of $\mathrm{O}_{2}^{-}$and $\mathrm{H}_{2} \mathrm{O}_{2}$ by hematoporphyrin derivative in the $\mathrm{pH}$ range 3-6.5 which we observed in the presence of cysteine or glutathione can be assigned most conveniently to an aggregated species of hematoporphyrin derivative. We envisage a process in which the thiol reduces 
an excited species of hematoporphyrin derivative within such an aggregate. The reduced hematoporphyrin derivative component in turn reduces oxygen to $\mathrm{O}_{2}^{\bar{*}}$. The hematoporphyrin derivative distribution diagram of Pottier and Kennedy $[34,35]$ suggests that maximum aggregation will occur at $\mathrm{pH} 3.5-4.0$. As the $\mathrm{pH}$ of the hematoporphyrin derivative environment increases, monomerization of hematoporphyrin derivative occurs. Our study has demonstrated that the yield of ${ }^{1} \mathrm{O}_{2}$ also increases. Keene et al. [36] have noted a similar effect of detergent upon the yield of ${ }^{1} \mathrm{O}_{2}$ sensitized by dihematoporphyrin ester, and have also proposed a disaggregation model. The increase in $\mathrm{pH}$ also favors ionization of the cysteine thiol.

Similar oxygen consumption profiles have been observed with other sensitizers and cysteine [37-39]. This, taken with the increased oxygen uptake in ${ }^{2} \mathrm{H}_{2} \mathrm{O}$ and the quenching of the $1268 \mathrm{~nm}$ emission of ${ }^{1} \mathrm{O}_{2}$ by thiols, is consistent with the chemical quenching of ${ }^{1} \mathrm{O}_{2}$ by the ionized thiol group of cysteine.

At $\mathrm{pH}<6.5$, a mechanism consistent with these observations and the observations of Felix et al. [18] that cellular reducing agents can reduce hematoporphyrin triplet is:

$$
\begin{aligned}
& \mathrm{HPD}+h \nu \rightarrow{ }^{1} \mathrm{HPD}^{*} \\
& { }^{1} \mathrm{HPD}^{*} \rightarrow{ }^{3} \mathrm{HPD} * \\
& { }^{3} \mathrm{HPD}^{*}+\mathrm{Cys}-\mathrm{SH} \rightarrow \mathrm{HPD}^{-}+\mathrm{Cys}-\mathrm{S}^{-}+\mathrm{H}^{+} \\
& \mathrm{HPD}^{-}+\mathrm{O}_{2} \rightarrow \mathrm{HPD}+\mathrm{O}_{2}^{\mp}
\end{aligned}
$$

where we have ignored potential intermediate reactions between aggregated hematoporphyrin derivative molecules. At high $[\mathrm{Cys}-\mathrm{SH}] /\left[\mathrm{O}_{2}\right]$ we would expect:

$$
\begin{aligned}
& \text { Cys-S }{ }^{\cdot}+\text { Cys-SH } \rightarrow \text { Cys- }^{-}{ }^{-}-\mathrm{S}-\text { Cys }+\mathrm{H}^{+} \\
& \text {Cys-S }{ }^{\top}-\mathrm{S}-\mathrm{Cys}+\mathrm{O}_{2} \rightarrow \text { Cys-S-S-Cys }+\mathrm{O}_{2}^{\top}
\end{aligned}
$$

while at low $[\mathrm{Cys}-\mathrm{SH}] /\left[\mathrm{O}_{2}\right]$ ratios

$$
\text { Cys-S }^{\circ}+\mathrm{O}_{2} \rightarrow \text { Cys-SOO }
$$

Cys-SOO $+3 / 2 \mathrm{O}_{2}+3 \mathrm{H}^{+} \rightarrow$ Cysteic acid $+\mathrm{H}_{2} \mathrm{O}_{2}$
This mechanism is consistent with the observations of Gennari et al. [40] using crystal violet in which they observed the production of cysteic acid and $\mathrm{H}_{2} \mathrm{O}_{2}$. Crystal violet does not sensitize ${ }^{1} \mathrm{O}_{2}$ production [41].

At $\mathrm{pH}>$ approx. 6.5 the following appears to dominate:

${ }^{3} \mathrm{HPD}^{*}+{ }^{3} \mathrm{O}_{2} \rightarrow{ }^{1} \mathrm{O}_{2}+\mathrm{HPD}$

${ }^{1} \mathrm{O}_{2}+\mathrm{Cys}_{-} \mathrm{S}^{-} \rightarrow \mathrm{Cys}^{-\mathrm{SOO}^{-}}$

and, as suggested by Straight [39],

$$
\begin{aligned}
& \text { Cys-SOO } \\
& -+\mathrm{H}_{2} \mathrm{O} \rightarrow\left(\mathrm{Cys}_{-} \mathrm{SO}^{+}\right)+2 \mathrm{OH}^{-} \\
& \left(\mathrm{Cys}-\mathrm{SO}^{+}\right)+\mathrm{Cys}^{-} \mathrm{S}^{-}+\mathrm{H}_{2} \mathrm{O} \rightarrow \mathrm{Cys}-\mathrm{S}-\mathrm{S}-\mathrm{Cys}+2 \mathrm{OH}^{-}
\end{aligned}
$$

This mechanism accounts for the lack of $\mathrm{H}_{2} \mathrm{O}_{2}$ production observed above $\mathrm{pH} 6.5$ and yet is consistent with the nearly quantitative disulfide formation reported by Jori and Spikes [38] using the $\mathrm{TPPS}_{4}-{ }^{-1} \mathrm{O}_{2}$ (TPPS $_{4}$ is meso-tetra-(4-sulfonatophenyl)porphin) photodynamic system, and also by Gennari et al. [40] using the proflavin $-{ }^{1} \mathrm{O}_{2}$ system. This mechanism parallels that suggested by Straight for the eosin-sensitized photooxidation of cysteine $[39,41]$.

NADH has been reported previously to produce $\mathrm{O}_{2}^{-}$with hematoporphyrin derivative and light [24]. Our spin trapping results confirm that hematoporphyrin derivative will sensitize the production of $\mathrm{O}_{i}^{-}$from NADH. Laser flash photolysis experiments have shown that NADH efficiently quenches ${ }^{1} \mathrm{O}_{2}[42,43]$.

${ }^{1} \mathrm{O}_{2}+\mathrm{NADH}^{k=8 \cdot 10^{7} \mathrm{M}^{-1} \cdot \mathrm{s}^{-1}} \mathrm{O}_{2}{ }^{7}+\mathrm{NAD}+\mathrm{H}^{+}$

For each $\mathrm{O}_{2}^{-}$produced in the above reaction an additional superoxide will be produced by NAD because of its very rapid reaction with oxygen [44]:

$\mathrm{NAD}+\mathrm{O}_{2}{ }^{k-1 \cdot 10^{9} \mathrm{M}^{-1} \cdot \mathrm{s}^{-1}} \mathrm{O}_{2}^{*}+\mathrm{NAD}^{+}$

The observations that NADH [24,43], ascorbate $[22,45]$, epinephrine [46] and many $N, N$-dimethylanilines of low oxidation potential [47] chemically quench singlet oxygen, yielding $\mathrm{O}_{2}^{-}$and $\mathrm{H}_{2} \mathrm{O}_{2}$, is 
consistent with the thermodynamic arguments of Koppenol [48]. However, we observed no evidence for $\mathrm{O}_{2}^{-}$formation in the quenching of ${ }^{1} \mathrm{O}_{2}$ by the cellular reducing agents, cysteine and glutathione. On thermodynamic grounds this is again reasonable because Ahmad and Armstrong [49] have estimated that $E^{0}\left(\mathrm{RS}^{*} / \mathrm{RS}^{-1}\right) \approx+1.1 \mathrm{~V}$, while for ${ }^{1} \mathrm{O}_{2}$ the one-electron reduction potential has been estimated to be $E^{0}\left({ }^{1} \mathrm{O}_{2} / \mathrm{O}_{2}^{-}\right) \approx+0.65 \mathrm{~V}$ [48]. Thus, the one-electron reduction of ${ }^{1} \mathrm{O}_{2}$ by cysteine is highly unlikely.

These results demonstrate that cellular thiols may be subject to attack by ${ }^{1} \mathrm{O}_{2}$ generated by hematoporphyrin derivative but that the hematoporphyrin derivative-photosensitized oxidation of thiols does not produce $\mathrm{O}_{2}^{-}$and $\mathrm{H}_{2} \mathrm{O}_{2}$ at physiological $\mathrm{pH}$. Nonetheless, cell damage and perhaps even cell death could be realized through inactivation of enzymes with critical thiols by ${ }^{1} \mathrm{O}_{2}$. Dubbelman et al. [50], in studying the photodynamic action of protoporphyrin on red cell ghosts, have found a loss of spectrin-associated ATPase activity. This loss of activity was not associated with the observed crosslinking of membrane proteins and was attributed to a rapid photooxidation of thiol groups. Van Steveninck et al. [51] have found that hematoporphyrin derivative and $\mathrm{Cu}^{2+}$ form a stable complex. This complex did not act as a photosensitizer for histidine, tryptophan, tyrosine, methionine or guanosine; however, an increased rate of sulfhydryl photooxidation compared to hematoporphyrin derivative was observed. Illumination of intact erythrocytes in the presence of the Photofrin- $\mathrm{Cu}^{2+}$ complex resulted in $\mathrm{K}^{+}$ leakage and photohemolysis, a process that could certainly be mediated through the oxidation of membrane-bound sulfhydryl groups with hematoporphyrin derivative [52]. Taken together, these results suggest that sulfhydryl groups may be an important target for the observed photodynamic effects of hematoporphyrin derivative.

\section{Acknowledgements}

Parts of this work were done while G.R.B. was at Wabash College; thus he gratefully acknowledges NSF equipment grants No. PRM-8109079 and No. TFI 8019273 as well as the support of the Research Corporation and the Haines Fund.
G.R.B. was a recipient of an NIH-NRSA award, No. 3 F33 ES05285-01S1.

\section{References}

1 Dougherty, T.J., Potter, W.R. and Weishaupt, K.R. (1984) in Porphyrins in Tumor Phototherapy (Andreoni, A. and Cubeddu, R., eds.), pp. 23-35, Plenum Publishing Corp., New York

2 Kessel, D. (1984) Photochem. Photobiol. 39, 851-859

3 Kessel, D. and Cheng, M.-L. (1985) Cancer Res. 45, 3053-3057

4 Kessel, D. (1986) Photochem. Photobiol. 44, 193-196

5 Gomer, C.J. and Dougherty, T.J. (1979) Cancer Res. 39, $146-151$

6 Gomer, C.J., Rucker, N., Mark, C., Benedict, W.F. and Murphree, A.L. (1982) Invest. Ophthalmol. Visual Sci. 22, $118-120$

7 Gregorie, H.B., Horger, E.O., Ward, J.L., Green, J.F., Richards, T., Robertson, H.C. and Stevenson, T.B. (1968) Ann. Surg. 167, 820-828

8 Lee See, K., Forbes, I.J. and Betts, W.H. (1984) Photochem. Photobiol. 39, 631-634

9 Mitchell, J.B., McPherson, S., DeGraff, W., Gamson, J., Zabell, A. and Russo, A. (1985) Cancer Res. 45, 2008-2011

10 Gomer, C.J. and Razum, N.J. (1984) Photochem. Photobiol. 40, 435-439

11 Moan, J., Petersen, E.O. and Christensen, T. (1979) Br. J. Cancer 39, 398-407

12 Weishaupt, K.R., Gomer, C.J. and Dougherty, T.J. (1976) Cancer Res. 36, 2326-2329

13 Das, M., Dixit, R., Mukhtar, H. and Bickers, D.R. (1985) Cancer Res. 45, 608-615

14 Hariharan, P.V., Courtney, J. and Elecczko, S. (1980) Int. J. Radiat. Biol. 37, 691-694

15 Bonnett, R., Lambert, C., Land, E.J., Scourides, P.A., Sinclair, R.S. and Truscott, T.G. (1983) Photochem. Photobiol. $38,1-8$

16 Buettner, G.R. and Oberley, L.W. (1980) FEBS Lett. 121, $161-164$

17 Cannistraro, S. and Van de Vorst, A. (1977) Biochem. Biophys. Res. Commun. 74, 1177-1185

18 Felix, C.C., Reszka, K. and Sealy, R.C. (1983) Photochem. Photobiol. 37, 141-143

19 Reszka, K. and Sealy, R.C. (1984) Photochem. Photobiol. 39, 293-299

20 Gibson, S.L., Cohen, H.J. and Hilf, R. (1984) Photochem. Photobiol. 40, 441-448

21 Reddi, E., Jori, G., Rodgers, M.A.J. and Spikes, J.D. (1983) Photochem. Photobiol, 38, 639-645

22 Buettner, G.R. and Need, M.J. (1985) Cancer Lett. 25, 297-304

23 Buettner, G.R. (1984) FEBS Lett. 177, 295-299

24 Frenkel, A.W., Jahnke, L.S. and Petryka, Z.J. (1981) in Oxygen and Oxy-Radicals in Chemistry and Biology (Rodgers, M.A.J. and Powers, E.L., eds.), pp. 634-635, Academic Press, New York 
25 Buettner, G.R. and Oberley, L.W. (1978) Biochem. Biophys. Res. Commun. 83, 69-74

26 Hamer, J. and Macaluso, A. (1964) Chem. Rev. 64, 473-495

27 Poletti, A., Murgia, S.M., Pasqua, A., Reddi, E. and Jori, G. (1984) in Porphyrins in Tumor Phototherapy (Andreoni, A. and Cubeddu, R., eds.), pp. 37-43, Plenum Press, New York

28 Lumry, R., Smith, E.L. and Glantz, R.R. (1951) J. Am. Chem. Soc. $73,4330-4340$

29 Hall, R.D. and Chignell, C.F. (1987) Photochem. Photobiol. 45 , in the press

30 Buettner, G.R. (1982) in Superoxide Dismutase (Oberley, L.W., ed.), Vol. 2, pp. 63-81, CRC Press, Boca Raton

31 Janzen, E.G. (1980) in Free Radicals in Biology (Pryor, W.A., ed.), Vol. 4, pp. 116-154, Academic Press, New York

32 Rodgers, M.A.J. (1985) in Primary Photo-processes in Biology and Medicine (Bensasson, R.V., Jori, G., Land, E.J. and Truscott, T.G., eds.), pp. 181-195, Plenum Press, New York

33 Lindig, B.A. and Rodgers, M.A.J. (1981) in Oxygen and Oxy-Radicals in Chemistry and Biology (Rodgers, M.A.J. and Powers, E.L., eds.), pp. 687-689, Academic Press, New York

34 Pottier, R. and Kennedy, J. (1985) in Primary Photoprocesses in Biology and Medicine (Bensassaon, R.V., Jori, G., Land, E.J. and Truscoitt, T.G., eds.), pp. 345-347, Plenum Press, New York

35 Pottier, R., Laplante, J.P., Chow, Y.-F.A. and Kennedy, J. (1985) Can. J. Chem. 63, 1463-1467

36 Keene, J.P., Kessel, D., Land, E.J., Redmond, R.W. and Truscott, T.G. (1986) Photochem. Photobiol. 43, 117-120

37 Fishman, P.H., Kusiak, J.W. and Bailey, J.M. (1973) Biochemistry $12,2540-2544$
38 Jori, G. and Spikes, J.D. (1984) in Topics in Photomedicine (Smith, K.C., ed.), pp. 183-319, Plenum Press, New York

39 Straight, R.C. (1979) Photodynamic Action, Sensitized Photooxidation Processes and Eosin-Sensitized Photooxidation of Cysteine, Ph.D. Dissertation, University of Utah

40 Gennari, G., Cauzzo, G. and Jori, G. (1974) Photochem. Photobiol. 20, 497-500

41 Straight, R.C. and Spikes, J.D. (1985) in Singlet $\mathrm{O}_{2}$ (Frimer, A.A., ed.), Vol. IV, pp. 91-143, CRC Press, Boca Raton

42 Peters, G. and Rodgers, M.A.J. (1980) Biochem. Biophys. Res. Commun. 96, 770-776

43 Peters, G. and Rodgers, M.A.J. (1981) Biochim. Biophys. Acta 637, 43-52

44 Land, E.J. and Swallow, A.J. (1971) Biochim. Biophys. acta $234,34-42$

45 Chou, P.-T. and Kahn, A.U. (1983) Biochem. Biophys. Res. Commun. 115, 932-937

46 Jahnke, L.S, and Frenkel, A.W. (1978) Photochem. Photobiol. 28, 517-523

47 Saito, I. and Matsuura, T. (1984) in Oxygen Radicals in Chemistry and Biology (Bors, W., Saran, M. and Tait, D., eds.), pp. 533-538, Walter de Gruyter, Berlin

48 Koppenol, W.H. (1976) Nature 262, 420-421

49 Ahmad, R. and Armstrong, D.A. (1984) Can. J. Chem. 62 , 171-177

50 Dubbelman, T.M.A.R., De Goeij, A.F.P.M. and Van Steveninck, J. (1978) Photochem. Photobiol. 28, 197-204

51 Van Steveninck, J., Boegheim, J.P.J. and Dubbelman, T.M.A.R. (1985) Biochim. Biophys. Acta 821, 1-7

52 Moan, J. and Vistnes, A.I. (1986) Photochem. Photobiol. $44,15-19$ 